\title{
Beyond Success or Failure: Sindhi Nationalism and the Social Construction of the "Idea of Sindh"
}

\author{
Julien Levesque | ORCID: 0000-0002-5446-7840 \\ Department of Political Science, Ashoka University, Sonepat, India \\ julien.levesque@ashoka.edu.in
}

\begin{abstract}
The study of Sindhi nationalism has remained overdetermined by the question of the allegiance of Sindhis to the Pakistani state. The movement has not been examined for itself but only from the vantage point of its success or failure. As a result, it has mainly received attention when sudden outbursts of violence seemed to threaten the stability of the state. However, few have attempted to examine what connects disparate events of ethnic violence and opposition to the central state with a broader understanding of what being Sindhi entails. Rather than address questions of failure or success, this article shows that the construction of a nationalist "idea of Sindh" has been a continuous process throughout the twentieth and twenty-first centuries. It also illustrates how an aspirational middle-class played a central role in this process. The article focuses on how three generations of Muslim men, who shared similar trajectories yet have unique social characteristics and repertoires of contention, constructed, reinforced, and disseminated the Sindhi nationalist discourse. This process translated into institution-building in the cultural sphere and contributed to the political outlook of a large section of Sindhi politicians on the left of the spectrum.
\end{abstract}

\section{Keywords}

ethnic nationalism - identity construction - nationalist mobilization - nationbuilding - cultural policy 
In the aftermath of former Prime Minister Benazir Bhutto's assassination on December 27, 2007, thousands of angry protesters took to the streets in Pakistan, destroying and burning cars, trucks, trains, buses, government offices, police stations, and other state symbols. This rage was most potent in the southern Sindh province, where disturbances lasted for several days, fueled by the slogan "Na khape, na khape, Pakistan na khape?" (We don't want/need Pakistan). By chanting in this way their separatist temptations, many Sindhis expressed the feeling of being directly targeted by the killing of the woman they affectionately called "Bibi" ( sister) or "Sindh Rani" (the queen of Sindh). To them, almost thirty years after the execution of Zulfiqar Ali Bhutto, the state of Pakistan was once more responsible for the death of a Sindhi political leader. It took Benazir Bhutto's widower Asif Ali Zardari's intervention for the public show of anger to subdue. He urged demonstrators to set aside their call for independence by reversing their slogan and declaring: "Pakistan khape."

The tension following Bhutto's assassination is indicative of the uneasy relationship that many Sindhis have expressed vis-à-vis the state of Pakistan since independence in 1947. However, observers generally dismiss the political implications of resentment among Sindhis by pointing Sindhi nationalist parties' poor showings in elections and their incapacity to build a mass movement, let alone obtain independence. ${ }^{1}$ For this reason, Sindhi nationalism is often described as a political failure. ${ }^{2}$ As a result, it has received little attention from journalists and scholars alike, who seem only to take interest when sudden outbursts of violence threaten the stability of the state. Indeed, most studies on Sindhi identity politics focus on the 1980s, when an anti-state uprising provoked harsh military repression, and ethnic conflict deepened the rift between various groups living in Sindh. ${ }^{3}$ In the main narrative of Pakistan's political history, debates on Sindhi identity and the related question of the level of political power Sindhis should exert in Pakistan appear as little but a sub-plot. Instead, civil-military tensions and the contested place of Islam in the state occupy the main stage. Matters of inter-province conflict tend to be seen from the vantage point of Pakistan's federalism and the state's difficulty

1 Muhammad Sajid Khan, "Nationalist Parties in Electoral Politics of Sindh," Pakistan Journal of History and Culture 38.1 (2017): 143-171.

2 Michel Boivin, "Le Pakistan à l'épreuve de ses Nationalismes: GM Syed et l'échec du Mouvement Indépendantiste du Sind," Outre-Terre 24.1 (2010): 315-323.

3 Charles H. Kennedy, "The Politics of Ethnicity in Sindh," Asian Survey 31.10 (1991): 938-955; Sayed Mehtab Ali Shah, "Ethnic Tensions in Sindh and Their Possible Solution," Contemporary South Asia 6.3 (1997): 259-272. 
in dealing with "centrifugal forces." ${ }^{4}$ When Sindhi nationalism receives a mention, its study remains overdetermined by the question of the allegiance of Sindhis to the Pakistani state - thus overlooking the actions and the discourse of nationalist groups. ${ }^{5}$ The question of identity construction has been examined among diasporic Sindhis and Sindhis in India. ${ }^{6}$ However, there still lacks a detailed study of Sindhi identity construction in Pakistan. Indeed, few have attempted to examine what connects disparate events of ethnic violence and opposition to the central state with a broader understanding of what being Sindhi entails. ${ }^{7}$

This article partially fills this gap by taking a Sindhi-centric lens to propose a narrative of the birth and evolution of Sindhi nationalism throughout the twentieth and twenty-first centuries. It dovetails into current endeavors that seek to displace the somewhat dominant depiction of Pakistan as a state in constant crisis. Such scholarship reexamines Pakistan's political history in a way that gives more significant space to groups that have not necessarily held state power, such as oppositional and left movements. ${ }^{8}$ Defining Sindhi nationalism in a narrow sense as a radical anti-Pakistan movement poses a

4 Theodore P. Wright, "Center-Periphery Relations and Ethnic Conflict in Pakistan: Sindhis, Muhajirs, and Punjabis," Comparative Politics 23.3 (1991): 299-312; Kavita R. Khory, "National Integration and the Politics of Identity in Pakistan," Nationalism and Ethnic Politics 1.4 (1995): 23-43; Adeel Khan, Politics of Identity: Ethnic Nationalism and the State in Pakistan (New Delhi: Sage, 2005); Katharine Adeney, Federalism and Ethnic Conflict Regulation in India and Pakistan (New York: Palgrave Macmillan, 2007); Farhan Hanif Siddiqi, The Politics of Ethnicity in Pakistan: The Baloch, Sindhi and Mohajir Ethnic Movements (London: Routledge, 2012).

5 A notable exception is the recent Asma Faiz, In Search Lost Glory: Sindhi Nationalism in Pakistan (London: Hurst Publishers, 2021).

6 Mark-Anthony Falzon, Cosmopolitan Connections: The Sindhi Diaspora, 1860-200o (Leiden: Brill Academic Publishers, 2004); Rita Kothari, The Burden of Refuge (New Delhi: Orient Blackswan, 2007); Nandita Bhavnani, The Making of Exile: Sindhi Hindus and the Partition of India, 2014 Edition (Chennai: Westland, 2014).

7 Tariq Rahman, "Language and Politics in a Pakistan Province: The Sindhi Language Movement," Asian Survey 35.11 (1995): 1005-1016; Tariq Rahman, "Language, Politics, and Power in Pakistan: The Case of Sindh and Sindhi," Ethnic Studies Report 17.1 (1999); Tanvir Ahmad Tahir, Political Dynamics of Sindh, 1947-1977 (Karachi: Pakistan Study Centre, University of Karachi, 2010); Oskar Verkaaik, Migrants and Militants: Fun and Urban Violence in Pakistan (Princeton: Princeton University Press, 2004).

8 Naveeda Khan, ed., Beyond Crisis: Re-evaluating Pakistan (Routledge, 2012); Jürgen Schaflechner, Christina Oesterheld, and Ayesha Asif, eds., Pakistan: Alternative Imag(in) ings of the Nation-State (Oxford, New York: Oxford University Press, 2020); Kamran Asdar Ali, Surkh Salam: Communist Politics and Class Activism in Pakistan, 1947-1972 (Karachi: Oxford University Press, 2015); James Caron and Ananya Dasgupta, "Popular Culture, Radical Egalitarianism, and Formations of Muslim Selfhood in South Asia," South Asian History and Culture 7.2 (2016): 107-116. 
problem because it inevitably raises the question of its political success or failure. This article eschews Sindhi nationalism's capacity to obtain independence and instead redirects the focus on socio-political dynamics in Sindh and group cohesion, boundaries, and identity markers - in short, what Sindhi nationalism does. Moreover, moving beyond the question of the success or failure of Sindhi nationalism allows us to raise the question of its broader contributions to Pakistan's political life and the process of nation-building in Pakistan. One can approach Sindhi nationalism as a discourse (asserting Sindh's existence as a nation) or a movement (comprising promoters of the nationalist discourse). One can also approach it as a social process through which the nationalist understanding of group boundaries spreads and transforms society. This article attempts to link all three dimensions through a socio-historical account of Sindhi nationalism. Indeed, relegating the question of success or failure helps us see Sindhi nationalism as a continuous process, rather than through isolated moments or sporadic outbursts when it stepped onto the main stage of Pakistani politics.

Therefore, this article follows two aims. First, I examine the progressive and continuous elaboration of the Sindhi nationalist discourse through the twentieth and into the twenty-first centuries. I highlight the role of three distinct generations of Sindhi men and (in a much smaller number) women in conceptualizing and spreading Sindhi nationalism. While the three generations share certain features in their members' trajectories, each of them experiences a different historical context and brings its specific contribution to Sindhi nationalism. The second part of this article raises the broader contribution of Sindhi nationalism to Pakistan's politics. I investigate two aspects: how Sindhi nationalism translated institutionally in cultural policy; and how Sindhi nationalism participated in party politics. I conclude by suggesting that scholars examine Sindhi nationalism in its co-constructive relation with the Pakistani state's conception of nationhood.

\section{2 The Social Construction of the Idea of Sindh}

Moving away from the question of the success or failure of Sindhi nationalism helps us refocus on what nationalism does to shape and re-shape group boundaries. It invites us to concentrate on the way nationalist entrepreneurs seek to impose their understanding of the social world, or what sociologist Pierre Bourdieu named their "di-vision" of the social world. ${ }^{9}$ What is the Sindhi nationalist "di-vision" of the world, and how was it constructed? I suggest that

9 Pierre Bourdieu, Language and Symbolic Power (Harvard University Press, 1991), 190. 
the Sindhi nationalist discourse rests on an ethnic understanding of Sindh as a historical and socio-cultural unit that warrants autonomous political power. This "idea of Sindh" assumes cultural continuity since the Indus Valley civilization and essentializes Sindhi culture as defined by a set of symbols. These symbols include Sufi Islam and Sufi Saints (with a particular reference to Shah Abdul Latif Bhittai), language, "folk" culture and crafts, ajrak and topi, and selected historical figures. ${ }^{10}$ This article does not focus on the idea of Sindh itself but examines how it was crafted over time and by whom. Looking at the social moorings of the idea of Sindh indicates that its originators and proponents primarily belonged to the aspirational middle-class. This section first briefly traces the biography of the founding father and leading ideologue of Sindhi nationalism, G.M. Sayed (1904-1995). It then follows a three-generational narrative of the construction the idea of Sindh, a process marked by collective mobilizations and informed by the social and political transformations affecting the region. ${ }^{11}$

10 Sarah Ansari, "A Way of Life Rather Than an Ideology?' Sufism, Pīrs, and the Politics of Identity in Sindh," in Modern Sufis and the State: The Politics of Islam in South Asian and Beyond, eds. Katherine Pratt Ewing and Rosemary R. Corbett (New York: Columbia University Press, 2020), 177-193; Julien Levesque, "Sindhis Are Sufi by Nature': Sufism as a Marker of Identity in Sindh," in Islam, Sufism and Everyday Politics of Belonging in South Asia, eds. Deepra Dandekar and Torsten Tschacher (London \& New-York: Routledge, 2016), 212-227; Michel Boivin, The Sufi Paradigm and the Makings of a Vernacular Knowledge in Colonial India: The Case of Sindh, 1851-1929 (Palgrave Macmillan, 2020); Pei-Ling Huang, "Between Faqīr and Fankār? Sounding Complex Subjectivities through Shah Jo Rāg in Sindh, Pakistan," Yearbook for Traditional Music 52 (2020): 41-67.

11 I do not propose using generational analysis in a mechanical approach but rather highlighting what Bryan S. Turner has called "generational consciousness." Building on Karl Mannheim's work, Turner defines "a generation as an age cohort that comes to have social significance by virtue of constituting itself as cultural identity. It is the interaction between historical resources, contingent circumstances, and social formation that makes 'generation' an interesting sociological category." Turner further defines a "strategic generation": "one that, given a condition or set of objectively favorable circumstances, can create a potent generational consciousness or ideology of political change that is sufficient to bring about potent social change" (Bryan S. Turner, "Strategic Generations: Historical Change, Literary Expression, and Generational Politics," in Generational Consciousness, Narrative, and Politics, eds. June Edmunds and Bryan S. Turner [Lanham, Maryland: Rowman and Littlefield, 2002], 28). Here, we focus on the role of education and political socialization in the emergence of successive generations, which each, in their respective socio-historical context, contributes to Sindhi nationalism. Classic approaches to political socialization tended to focus on the impact of the family environment on political behavior. See Herbert Hyman, Political Socialization. A Study in the Psychology of Political Behavior (New York: Free Press, 1959). However, recent scholarship has highlighted the existence of other spaces of political socialization in childhood and the importance of "secondary socialization" in the formation of political subjects. See Simone Abendschön, ed., Growing into Politics: Contexts and Timing of Political Socialisation (ECPR Press, 2013); 
2.1 The Political Itinerary of Sindhi Nationalism's Main Ideologue

In his inaugural speech to the December 1943 Annual Session of the All-India Muslim League that took place in Karachi, G.M. Sayed described Pakistan as the Indus valley restored to its former political unity:

I welcome you all to the land of Sindhu. By Sindhu I mean that part of the Asian continent which is situated on the borders of the river Indus and its tributaries. But as time went on the name began to connote a smaller and smaller area, until now it is assigned only to that part of the land which is watered by tail end of this great river. Today again fully aware of this fact, we are moving to weld together these different parts into one harmonious whole, and the new proposed name, Pakistan connotes the same old Sindhu land.12

At the time, G.M. Sayed was one of Sindh's main protagonists of the Muslim League, the party that campaigned to establish a Muslim state in India. A few months earlier, in March 1943, he had moved a resolution in the provincial assembly by which Sindh endorsed the Pakistan project and was the first province to do so. Convinced to act in the best interest of Sindh, G.M. Sayed then promoted the Pakistan project. However, he later turned against the state and is now remembered by many as a traitor who advocated a separate Sindh.

G.M. Sayed was born in 1904 in colonial Sindh. The British had annexed Sindh to their colonial possessions after defeating its rulers, the Talpurs, in 1843. For most of the colonial period, the British administered Sindh as part of the Bombay Presidency but made it a separate province in $1936 .{ }^{13}$ G.M. Sayed was born the heir of a spiritual lineage, a sayyid - a person thought to descend from Prophet Muhammad - and a sajjada nashin - the hereditary custodian of a Sufi saint's mausoleum. Thanks to these qualities, he was invited to participate in political meetings at an early age. In February 1920, Makhdum Moinuddin of Khiyari asked him to the first provincial session of the Khilafat movement, which fought against the abolition of the Caliphate following

Lucie Bargel and Muriel Darmon, "Socialisation Politique: Moments, Instances, Processus et Définitions du Politique," August 24, 2017 (https://hal.archives-ouvertes.fr/hal-o1576832 [accessed August 8, 2021]).

12 Tahir, Political Dynamics of Sindh, 1947-1977, 123.

13 Matthew A. Cook, Annexation and the Unhappy Valley: The Historical Anthropology of Sindh's Colonization (Leiden: Brill, 2015); Hamida Khuhro, The Making of Modern Sindh: British Policy and Social Change in the Nineteenth Century (Karachi: Oxford University Press, 1999). 
World War I..$^{14}$ Being a sayyid and sajjada nashin bears particular significance in the religious context of Sindh. According to Kumar and Kothari, Sindh has "non-textualized religious practices" in which shrine worship plays a central role. ${ }^{15}$ Some authors attribute these characteristics to Sindh's relative isolation from the main power centers - a "simplistically static picture" of Sindh as a margin that scholars are now beginning to re-evaluate. ${ }^{16}$ Endowed with a pedigree that made people look up to him for leadership, G.M. Sayed emerged in the late 1930 as a pro-Pakistan Muslim Leaguer. Although he had previously done a stint in the Congress Party, he now agitated on "communal" terms during the Masjid Manzilgah affair, a conflict between Hindus and Muslims over the use of a religious place. ${ }^{17}$

However, G.M. Sayed soon fell out with the Muslim League and its central leader, Muhammad Ali Jinnah, and the party eventually expelled him in 1946. While he had previously propounded the Pakistan project, he now began to fear negative fallouts of the birth of the new country for Sindh. Indeed, on August 14, 1947, Pakistan's independence initiated tremendous demographic, social, and economic change as Sindh became the political and economic center of the new country. Karachi became the capital of Pakistan: the city not only hosted the new federal administration but also, along with other main urban centers of Sindh, offered shelter to hundreds of thousands of (mainly) Urdu-speaking refugees from India. By 1949, more than 700,000 immigrants had settled in Sindh, which significantly affected the language balance when combined with the departure of many Sindhi Hindus and Sikhs in $1948 .{ }^{18}$ The number of native Sindhi speakers fell from 87 percent in 1941 to 67 percent in 1951 and 55.7 percent in $1981 .{ }^{19}$ This fact was particularly the case in Karachi, as

14 Sarah Ansari, Sufi Saints, and State Power: The Pirs of Sind, 1843-1947 (Cambridge: Cambridge University Press, 1992), 87; Khadim Hussain Soomro, The Path Not Taken: G.M. Sayed, Vision and Valour in Politics (Sehwan Sharif: Sain Publishers, 2004), 13.

15 Priya Kumar and Rita Kothari, "Sindh, 1947 and Beyond," South Asia: Journal of South Asian Studies 39.4 (2016): 774 .

16 Sarah Ansari, “At the Crossroads? Exploring Sindh's Recent Past from a Spatial Perspective," Contemporary South Asia 23.1 (2015): 7-25; Manan Ahmed Asif, "Quarantined Histories: Sindh and the Question of Historiography in Colonial India - Part I," History Compass 15.8 (2017); Manan Ahmed Asif, "Sindh and the Question of Historiography in Colonial India Part II," History Compass 15.8 (2017).

17 Hamida Khuhro, "Masjid Manzilgah, 1939-40: Test Case for Hindu-Muslim Relations in Sind," Modern Asian Studies 32.1 (1998): 49-89.

18 Sarah Ansari, “Pakistan's 1951 Census: State-Building in Post-Partition Sindh," South Asia: Journal of South Asian Studies 39.4 (2016): 825 .

19 Soofia Mumtaz, "The Dynamics of Changing Ethnic Boundaries: A Case Study of Karachi," The Pakistan Development Review 29.3/4 (1990): 223-248. 
the city swelled in the years after partition. From about 435,000 inhabitants in 1941, its population rose to 1,126,ooo in ten years. The city is now often thought to host more than twenty million inhabitants (although the last census in 2017 counted a little under 15 million people). Various subsequent waves of migration into Sindh kept fueling population growth.

These changes fed G.M. Sayed's disaffection with Pakistan. The state's repressive moves to thwart his political initiatives did not help: between 1958 and 1966, G.M. Sayed was under house arrest. This period was also when, during Ayub Khan's military dictatorship, Sindh was merged with West Pakistan under the One Unit scheme. After Pakistan's independence, G.M. Sayed gradually elaborated his thought and developed a framework to think about Sindh in nationalist terms that viewed the region as a cultural and historical entity that deserved to exist as a political unit. His numerous writings over four decades brought variegated tropes into a coherent nationalist discourse. He dwelled, for instance, on Shah Abdul Latif, an eighteenth-century Sufi, as a "national poet" of Sindh, Sindh's particular spirituality beyond religious practice, the continuity of Sindhi culture through history, or the heroes of Sindh's past. ${ }^{20}$

But the main turn in G.M. Sayed's political career happened in late 1973 when he declared himself in favor of Sindh's independence. Two years after the formation of Bangladesh, G.M. Sayed, who had expressed support for the demands of the Bengali leader Mujibur Rahman before the latter turned separatist, radicalized his political rhetoric and embraced the cause of an independent Sindh - "Sindhudesh."21 Several causes may explain this radicalization: the independence of Bangladesh, G.M. Sayed's total distrust of the Pakistan army and central authorities following the bloody military operation against Bengali and Baloch separatists, and his disappointment with Zulfiqar Ali Bhutto, who showed himself ready to compromise with the army in his quest for power. In his writings, G.M. Sayed described the adoption of a separatist stance as the last option. Indeed, a reluctance might be inferred from the absence of any sudden grand or bellicose declaration of separatism. Instead, his new political outlook seems to have taken shape progressively throughout multiple public speeches in 1972 and $1973 .{ }^{22}$ His later books clearly argued for

20 G.M. Sayed, Shah Latif and His Message (Sehwan Sharif: Saeen Publishers, 1996); G.M. Sayed, Religion and Reality (Lahore: Fiction House, 1986); G.M. Sayed, Sindhudesh: A Study in Its Separate Identity Through the Ages (Karachi: G.M. Syed Academy, 1991); Jī Em Sayyidu, Sindhī Kalcaru; Tahzību. (Karācī: Na'iyanu Sindhu Pablisharz, 1972).

21 Both leaders had also met in Karachi in the late 196os.

22 Many online and printed biographical accounts of G.M. Sayed's life state that he declared himself in favor of independence on his 68th birthday in January 1972. However, the speech calls for trusting Zulfiqar Ali Bhutto as the "last chance to save Pakistan." Interviews 
Sindh to become free and for the break-up of Pakistan. ${ }^{23}$ His political party, the Jiye Sindh Mahaz, and its student wing became public advocates of Sindh's independence. In the political arena at this time, G.M. Sayed grew more isolated. His 1970 campaign had been an utter failure. He was placed under house arrest by Z.A. Bhutto's government in August 1972 because it viewed him as fueling ethnic tensions in the wake of the provincial government's attempt to restore the official status of Sindhi.

Nonetheless, G.M. Sayed's political stance, if obstinate, often seemed ambiguous to observers. Justified in terms of the pursuit of "Sindhis' rights," his support for the separatist cause appeared at times blind to the actual suffering of Sindhis. G.M. Sayed, driven by his opposition to Z.A. Bhutto, his family, and his political legacy, refused to support the Movement for the Restoration of Democracy (MRD) in 1983, a multi-party coalition led by late Bhutto's daughter Benazir and her Pakistan People's Party (PPP). The military violently crushed the massive uprising in Sindh, but G.M. Sayed did not budge. Although he argued that the MRD stood for the preservation of Pakistan while he sought to break it, many saw this move as personal rivalry trumping political concerns. It eroded his credibility by making him appear as an apologist of Zia ul-Haq's military dictatorship. On the other hand, the two crucial actors of the MRD in Sindh - the PPP and the Awami Tehreek - gained immense popularity as the parties who fought against the army's might.

At the same time, G.M. Sayed's support for the separatist cause also sometimes seemed to falter. In 1984, his failed attempt to bring a non-separatist at the helm of the JSM only served to accentuate the discrepancy between the leadership and the activists, who vehemently reiterated the Sindhudesh cause. ${ }^{24}$ G.M. Sayed seemed ready to forego the pursuit of independence when he could make electoral gains. When democracy returned to the country in 1988, he attempted to bring several parties into an electoral alliance, the Sindh National Alliance (Sindh Qaumi Ittehad). ${ }^{25}$ However, after initial negotiations, the other leading player, Rasul Bakhsh Palijo, and his Awami Tehreek messed

and my study of his speeches' transcripts indicate a progressive shift rather than a clear rupture point.

23 Jī Em Sayyidu, Pākistān Hāṇi Tuṭaṇu Ghurje? (Hyderabad, Pakistan: publisher not identified, 1988).

24 This individual was the respected historian Hamida Khuhro, who, before entering politics, taught at the University of Sindh. Her father, Muhammad Ayub Khuhro, was a prominent politician who served thrice as Chief Minister of Sindh and was a friend (and occasional political associate) of G.M. Sayed. More detail in the next section on his role in Sindhi nationalism.

25 The SNA included the Jiye Sindh Mahaz, the Awami Tehreek, and the Pakistan National Party led by Ghaus Bakhsh Bizenjo. According to Abdul Khalique Junejo, G.M. Sayed 
up the project by refusing to allow space for Sindh's Urdu-speaking population, represented by the Mohajir Qaumi Movement. To him, the proposed alliance had to be named "Sindhi National Alliance" (Sindhi QaumiIttehad) - a coalition of and for ethnic Sindhis - rather than "Sindh National Alliance" - including all populations of Sindh. Meanwhile, in a period of acute ethnic tension that soon led to repeated violent conflict in 1988-1990, G.M. Sayed met with the MQM leader Altaf Hussain. The sNA fell apart, and its members or associates fared poorly in the 1988 elections, both in the national and provincial assemblies. Yet, the SNA allowed for nationalist parties (whether autonomist or separatist) to emerge as a pressure group that forced the elected PPP representatives to step back on specific issues. It was the case with a plan to repatriate "Biharis" from Bangladesh: Prime Minister Benazir Bhutto abandoned the project in 1989 when the SNA and the JSM protested it. ${ }^{26}$

In April 1995, G.M. Sayed died, leaving a fragmented and controversial heritage. But many of the issues that had nourished Sindhi resentment in the 1950s were still matters of conflict. It was true for the place of the Sindhi language and culture, the use, management, and distribution of resources (mineral, hydrocarbons, water, land), and the question of immigration into Sindh. According to the 2017 census, Sindh now has about 48 million people, or 23 percent of Pakistan's total population, for about 16 percent of the country's territory. Although the federal capital of Pakistan moved to Islamabad in the late 196os, Karachi remained the main harbor and the economic hub of the country, contributing the largest revenue share to the federal exchequer. ${ }^{27}$ In addition, the development of irrigated agriculture over the twentieth century and the discovery of natural resources (oil, gas, and coal) reinforced the economic importance and strategic position of Sindh.

\subsection{Colonial Policies and the "Separation" Generation (1920s-1940s)}

The nationalist idea of Sindh did not emerge with G. M. Sayed but under colonial rule when a section of the Sindhi political elite fought to establish a separate Sindhi province. A century (1843-1947) of colonial policies impacted both the culture and social structures of Sindh in at least two significant respects. First, the British administration fixed Sindh's current borders and

initiated this alliance on the advice of the great communist figure Jam Saqi to counter Rasul Bakhsh Palijo's project to establish a "Sindhi People's National Alliance."

26 Kennedy, "The Politics of Ethnicity in Sindh," 951.

27 Laurent Gayer, Karachi: Ordered Disorder and the Struggle for the City (London: Hurst \& Company, 2014). 
exerted (or aimed to) its authority uniformly over the territory and its inhabitants. ${ }^{28}$ Second, the British rulers standardized the Sindhi language based on the central vicholi dialect, for which they invented a new modified Perso-Arabic Naskh script. The writing system allowed a single community of letters to emerge where multiple community-based scripts previously divided speakers of a common language. ${ }^{29}$ Moreover, its promotion by the colonial state led to the emergence of a vernacular print culture with an active press, new writing styles, and the canonization of literary figures, such as the Sufi saint Shah Abdul Latif Bhitai. ${ }^{30}$ These developments allowed Sindhis to subsequently construct a nationalist discourse that revolved around a common literature and Sufism as an "ideological pillar" or "identity marker." ${ }^{31}$

Moreover, colonial history-writing placed Sindh at the center of the narrative of the spread of Islam in India. Colonial historiography thus "produced ... synthetic narratives [that] created the discursive grounds for Sindh as a political space."32 In addition, the "semi-representative electoral system" set up in Sindh, as in other parts of British India, de facto made it a political space by giving rise to the need "for the political classes ... to flatten out differences in the interests of producing a larger, more homogenous electoral community."33 Colonial policies thus "participate[d] in the creation and reification of social groups with their varied interests" by bringing about three elements - fixed

28 Muhammad Hussain Panhwar, Fixing of Boundaries of Sindh 1843-1947 (http://www .panhwar.net/FIXING\%2OOF\%2oBOUNDARIES\%2OOF\%2OSINDH\%201843-1947.pdf [accessed August 9, 2021]).

29 Ali Asani, "At the Crossroads of Indic and Iranian Civilizations. Sindhi Literary Culture," in Literary Cultures in History: Reconstructions from South Asia, ed. Sheldon Pollock (Berkeley: University of California Press, 2003); Michel Boivin, "Islam, Langues et Identités Régionales Dans l'Inde Coloniale: L'exemple Du Sindh (1851-1939)," Revue Des Mondes Musulmans et de La Méditerranée 124 (2008): 69-91.

$30 \quad$ Annemarie Schimmel, Sindhi Literature (Wiesbaden: Otto Harrassowitz Verlag, 1974); Michel Boivin, Historical Dictionary of the Sufi Culture of Sindh in Pakistan and India (Karachi: Oxford University Press, 2015).

31 Oskar Verkaaik, "The Sufi Saints of Sindhi Nationalism," in Interpreting the Sindhi World: Essays on Society and History, eds. Michel Boivin and Matthew A. Cook (Karachi: Oxford University Press, 2010), 196-215; Levesque, “Sindhis are Sufi by Nature', 212-227. Also see Michel Boivin's book The Sufi Paradigm and the Makings of a Vernacular Knowledge in Colonial India.

32 Asif, "Quarantined Histories," 2.

33 Adeem Suhail and Ameem Lutf, "Our City, Your Crisis: The Baloch of Karachi and the Partition of British India," South Asia:Journal of South Asian Studies 39.4 (2016): 894. 
borders, standardized language, reified culture - that created the necessary conditions for an "imagined community" to emerge in Sindh. ${ }^{34}$

Sindhis thus adopted new ways of conceptualizing their own culture. Political representatives in the 1920 s and 1930s projected Sindh as a single geographical, linguistic, cultural, and historical entity. According to them, Sindh deserved for this very reason to exist as a political entity. They argued for its separation from the Bombay Presidency and for it to be a province of its own. ${ }^{35} \mathrm{~A}$ few years before Gandhi took the leadership of the Indian National Congress and extended its reach beyond elite circles, the demand for a separate Sindh province was put forward in 1913 at the annual session of the INC in Karachi. Harchandrai Vishindas (a Hindu merchant) and Ghulam Muhammad Bhurgri (a Muslim landlord) stated that "the Province possesses several geographical and ethnological characteristics which give her the hallmark of a self-contained territorial unit." ${ }^{\prime 3}$ In the 1920 , much like India's politics, the project took on a communal tinge. On the one hand, many Sindhi Hindus withdrew their support to the scheme because a separate Sindh would turn them into a religious minority - they represented about one quarter of the total population. On the other hand, the Muslim League announced in 1925 its support to the "separation movement," hence making it a pan-Indian and a Muslim issue.

Although the justification for "Sindh's separation" hinged on economic and political terms, politicians ultimately framed the key moral argument in favor of a separate province in nationalist rhetoric that highlighted the historical and cultural continuity of Sindh. This nationalist framing appeared in what became the most well-known argumentative piece of that time, a 5o-page pamphlet entitled A Story of the Sufferings of Sindh: A Case for the Separation of Sind from the Bombay Presidency. Muhammad Ayub Khuhro, a 29-year-old Muslim landlord from the northern town of Larkana and head of the Khuhro caste, published it in $1930 .{ }^{37}$ According to Ayub Khuhro:

34 Bernard S. Cohn, Colonialism and its Forms of Knowledge: The British in India (Princeton: Princeton University Press, 1996), 22.

35 Hamida Khuhro, ed., Documents on Separation of Sind from the Bombay Presidency, Volume 1 (Islamabad: Institute of Islamic History, Culture, and Civilization, Islamic University, 1982); Philemon Mateke, "The Separation of Sind from the Bombay Presidency," Grassroots 2.2 (1988): 18-45.

$36 \quad$ Khuhro, Documents on Separation of Sind from the Bombay Presidency, Volume 1, 1.

37 Ayub Khuhro, A Story of the Sufferings of Sindh: A Case for the Separation of Sind from the Bombay Presidency (http://sanipanhwar.com/Sufferings\%20of\%2oSindh\%2oAyub\%20 Khuhro.pdf [accessed August 8, 2021]). 
The proof of the fact that Sind was a very important and a highly civilized country even 5000 years ago, is furnished by the recent discoveries made by the Indian Archaeological Department at Mohan-jo-Daro (Sind) ... I have briefly traced the history of Sind from 5000 years back down up to the British conquest and the Governorship of Sir Charles Napier. During the whole period, the historical record shows that Sind has never been unsurped [sic] by any other province and it is really inconceivable how British Government has deemed it right to allow the Bombay Presidency to swallow Sind. ${ }^{38}$

Ayub Khuhro's trajectory represents the generational experience of young elite Sindhi Muslims in the first half of the twentieth century. Khuhro, like many other sons of Muslim landowners of his era, was educated at the Sindh Madrassatul Islam in Karachi. Although Sindhi Hindus had long had access to a Western-type secondary and higher education, this was not the case for Sindhi Muslims before the establishment of the Sindh Madrassatul Islam in Karachi in 1885 and similar institutions subsequently founded in other towns and cities. ${ }^{39}$ Khuhro was elected to the Bombay Council in 1923, at the age of 22 , and was involved in organizations that sought to represent the Sindhi Muslim voice, such as the Sindh Provincial Conference, the Sindh Zamindar Association, or the Sindh branch of the National Mahommedan Association. ${ }^{40}$ For Khuhro, this implied moving to the centers of power, Bombay and Karachi, and leaving his hometown Larkana - without, however, severing ties, since he remained a large landowner and the head of the Khuhro clan. Although

38 Ibid., 203.

39 Such was especially true of the amil, a subcaste of administrators. For additional detail, see Claude Markovits, The Global World of Indian Merchants, 1750-1947: Traders of Sind from Bukhara to Panama (Cambridge: Cambridge University Press, 200o); Claude Markovits, "Urban Society in Colonial Sindh (1843-1947)," in Sindh Through History and Representations: French Contributions to Sindhi Studies, ed. Michel Boivin (Karachi: Oxford University Press, 2008), 42-51. Similar educational institutions were established across Sindh in the late nineteenth and early twentieth centuries, such as the Naushero Madrassah, the Larkana Madrassah, the Noor Muhammad High School in Hyderabad, and the madrassah in Tango Bago. These institutions, inspired by Sir Syed Ahmad Khan's Anglo-Oriental College at Aligarh, "played their part in training the young Sindhies [sic] to keep them familiar with their rights and interests as well as educating them [on] how to protect their rights" (Riaz Hussain, "The Sindh Muslim League: Formation, Problems, and Role in the Freedom Struggle of Pakistan," Pakistan Journal of History and Culture 32. 2 [2011]: 135-136).

40 Hamida Khuhro, "The Separation of Sind and the Working of an Autonomous Province: An Analysis of Muslim Political Organisation in Sind," Sindhological Studies (Summer 1982): 48 . 
Khuhro belonged to an exceptionally powerful family, his social profile nevertheless exemplifies what characterized the "separation movement" supporters - the "separation generation" - who formed the new Sindhi Muslim elite that entered the public arena in the 1920s. These men tended to be sons of Muslim landowners who had studied at the Sindh Madrassatul Islam. They followed a rural to urban migration to seek employment in non-manual urban sectors - administrative services, private professions, and in political institutions such as town councils.

After Sindh became a province in 1936, the new Sindhi Muslim elite increasingly endorsed the Muslim League's Pakistan project. The latter thus appears as a continuity of the former. Firstly, both movements framed their demands as a way for the new Muslim elite to access government employment and urban jobs. ${ }^{41}$ This framing implied getting rid of the domination of Hindu administrators (amil by caste) and businessmen (bhaiband), vilified as the "bania money-lenders" from whose "clutches" poor Muslims had to be relieved. ${ }^{42}$ Sindhi Hindu merchants were targeted because of the amount of land they had acquired through mortgages from Muslim landholders. ${ }^{43}$ Other groups were also perceived as harming the rights of the "indigenous population." "Numerical anxieties" were directed at Punjabis, who had recently settled in Sindh after the completion of the Sukkur barrage in $1932 .{ }^{44}$ What "being Sindhi" meant was now debated at the provincial assembly, with voices

41 Such demands fit into Hamza Alavi's framework in which the Independence movement in India didn't pit Hindus against Muslims. Instead, conflicts involved a particular class the "salariat" - among Hindus and Muslims, who competed for access to government employment (Hamza Alavi, "Pakistan and Islam: Ethnicity and Ideology," in State and Ideology in the Middle East and Pakistan, eds. Fred Halliday and Hamza Alavi [London: Macmillan Education, 1988], 64-111). The term salariat is problematic in our case, as most members of the new Muslim elite in Sindh drew their primary income from agricultural rent.

In a letter to G.M. Sayed dated June 7, 1926, the prominent Muslim League supporter Abdullah Haroon wrote: "I hope to do some solid work in the Assembly, in the direction of ameliorating the condition and improving the status of the Zamindars, relieving the poor Muslims from the clutches of the bania money-lenders, providing better facilities for the Hajj pilgrims, and granting of all powers of self-government to the sturdy Muslim population of the North-West Frontier Province, and advancing the economic, educational and political progress of our community in various other ways." Archive G.M. Sayed, file 6, International Institute of Social History, Amsterdam.

43 David Cheesman, Landlord Power and Rural Indebtedness in Colonial Sind, 1865-1901 (Surrey: Curzon Press, 1997); Haris Gazdar, "The Fourth Round, and Why They Fight on: An Essay on the History of Land and Reform in Pakistan," January 1, 2009 (https://www .researchgate.net/publication/241757053_The_Fourth_Round_And_Why_They_Fight_ On_An_Essay_on_the_History_of_Land_and_Reform_in_Pakistan [accessed August 8, 2021]).

Ansari, “Pakistan's 1951 Census," 821. 
asking for ethnic preference in government employment - notably that of G.M. Sayed. ${ }^{45}$ Secondly, some Sindhi Muslims projected the imagery used to support the demand for a separate Sindh into the Pakistan project, making it a Sindh-centric representation. ${ }^{46}$ The speech by G.M. Sayed quoted earlier suggests that there was in the 1940s a "Sindhi understanding" of the Pakistan project. We should also note that those who argued for the separation of Sindh and later for the Pakistan project excluded the Hindu and urban part of Sindh's culture from the imaginary of Sindhi nationalism. In doing so, they overlooked the significant contribution of Hindus to defining sindhiyyat or Sindhiness.

Both the separation movement and the Pakistan movement fed on the same emancipatory thrust that sought to place power in the hands of the majority population of Sindh, that is, Sindhi Muslims. Both aimed to give a common cause and representatives to Sindhi Muslims. Political representatives who came from the new Sindhi Muslim elite and spoke in the name of Sindh did not significantly change the way they conceived their role as they threw their weight behind the Pakistan project. As its entrance into the public arena eroded the old power nexus, the new Sindhi Muslim elite relied on a particular repertoire of contention - that of representative politics and press advocacy. ${ }^{47}$ Having understood that the claim to political autonomy had to rest on cultural unicity, these men laid the foundations of the Sindhi nationalist discourse by arguing that the cultural and historical specificity of Sindh justified it becoming a separate political entity. The same idea later found its way into the Pakistan project. This discourse invoked a set of cultural references that gained progressive acceptance as symbols of Sindh's cultural essence, such as Sufi saints and spirituality, the Indus civilization and Mohenjo-Daro, language, food, and dress.

\subsection{The "One Unit" Generation (1950s-196os)}

The political elite of the first generation of Sindhi nationalism could not cope with the gradual shrinking of the democratic space after Pakistan's independence. ${ }^{48}$ Some had already broken away from the Muslim League as soon as the mid-1940s. It was notably the case of G.M. Sayed following

45 Sarah Ansari, "Political Legacies of Pre-1947 Sind," in The Political Inheritance of Pakistan, ed. D.A. Low (Houndmills: Macmillan, 1991), 173-193.

46 On the growth of the Muslim League in Sindh, see Allen Keith Jones, Politics in Sindh 1907-1940: Muslim Identity and the Demand for Pakistan (Karachi: Oxford University Press, 2002).

47 What Markovits called the "wadero-bania nexus" (Markovits, The Global World of Indian Merchants, 2).

48 Khalid B. Sayeed, Pakistan: The Formative Phase (Karachi: Pakistan Publishing House, 1960). 
disputes with the All-India Muslim League's provincial (i.e., Ghulam Hussain Hidayatullah, Chief Minister and future governor of Sindh) and central (i.e., Muhammad Ali Jinnah) leadership. These disagreements led to his expulsion from the party, after which he established the Progressive League. ${ }^{49}$ G.M. Sayed was, at the time, close to left-leaning figures of Sindh like Hyder Bakhsh Jatoi and Muhammad Ibrahim Joyo. Jatoi resigned from his official position in 1945 to take the leadership of a peasant movement, the Sind Hari Committee. Muhammad Ibrahim Joyo was fired from the Sindh Madrassatul Islam in 1946 because of the publication of his book Save Sindh, Save the Continent: From Feudal Lords, Capitalists and Their Communalisms. ${ }^{50}$ G.M. Sayed was also in touch with other "regional" leaders (i.e., the Pashtun leader Abdul Ghaffar Khan and Prince Abdul Karim, brother of the Khan of Kalat of Baluchistan). He attempted to build with them loyal opposition parties that would work for a pluralist Pakistan. In May 1948, at G.M. Sayed's house in Karachi, Pakistan's first opposition party was founded, the People's Organization of Pakistan, the forebear of the National Awami Party (established in Dhaka in 1957). The intellectual environment of oppositional politics in Sindh's late 1940s and early 1950s brought together communists and those who would later be called nationalists: for instance, G.M. Sayed, who by 1953 was leading the opposition group in the Sindh Assembly, was also heading the Pakistan-Soviet Cultural Association. ${ }^{51}$ This ideological outlook would remain the backbone of political mobilization in Sindh in the following decades.

Sindhi politicians not engaging in oppositional politics also entertained a strained relationship with the central Pakistani leadership. This tension generated grievances that Sindhi nationalists still harbor against the Pakistani state. ${ }^{52}$ With the formation of Pakistan, Sindhi Muslims hoped to oversee the administration of their province. However, the central government forced the province to host large inflows of refugees, despite Chief Minister

49 Sometimes also called Sindh Progressive Muslim League in contemporary documents.

50 Lal Bux Jiskani, "The Hyder Bakhsh Jatoi Saga," Grassroots 3.1 (1979): 74-105; Oskar Verkaaik, "Reforming Mysticism: Sindhi Separatist Intellectuals in Pakistan," International Review of Social History 49.12 (2004): 65-86.

51 See the declassified CIA document "Pakistan-Soviet Cultural Association (PSCA)" dated December 7, 1953 (https://www.cia.gov/library/readingroom/document/cia-rdp8o-oo810 aoo2800550002-2 [accessed August 8, 2021]).

52 Sarah Ansari, "Partition, Migration, and Refugees: Response to the Arrival of Mohajirs in Sind During 1947-48," in Freedom, Trauma, Continuities. Northern India and Independence, eds. D.A. Low and Howard Brasted (New Delhi: Sage, 1998), 91-104; Sarah Ansari, Life After Partition: Migration, Community and Strife in Sindh, 1947-1962 (Karachi: Oxford University Press, 2005). 
M.A. Khuhro's resistance. Thus, Sindhi Muslim politicians did not enjoy the political autonomy they had supported the Pakistan movement for. Moreover, although Sindh had not witnessed extensive communal violence in the years leading up to partition, deadly riots in Karachi in January 1948 motivated many Sikhs and Hindus to leave for India. The riots sparked the rumor that they were engineered events aimed to make room for the incoming Muhajirs. The new capital Karachi and a large surrounding territory were administratively cut off from the province and made into a federal territory, occasioning a significant revenue loss for the provincial government, and causing the relocation of the newly established University of Sindh to Hyderabad. The central leadership also insisted that only Urdu be Pakistan's national language, a measure vehemently opposed by Sindhi (and Bengali) students. These grievances fed a new generation of Sindhi nationalism. The first generation was pushed to the margin when the One Unit constitutional set-up ended provincial electoral politics. Sindh became a part of the new province of West Pakistan, which stood equal to East Pakistan. Ayub Khan's military coup in 1958 brought a final closure to possibilities for elected representatives in the West Pakistan assembly to restore Sindh's status by abolishing One Unit.

While the first generation belonged to a new elite, the second generation was a rising and aspirational middle class, somewhat similar to what sociologist Hamza Alavi termed the "salariat." ${ }^{3}$ The social mobility of this group rested on measures adopted by their elders. In the 1940s, the Sindh government initiated educational measures which widened access to primary schooling (e.g., the Sind Primary Education Act of 1947) and established the province's first university in $1947 .{ }^{54}$ These measures not only increased the number of educated graduates in Sindh. It also made it possible for Sindhis to pursue higher education within the province, whereas the previous generation was compelled to study in other parts of the subcontinent. The number of higher education institutions increased in Sindh in the following decades. By 1974, there were 68 colleges affiliated to the University of Sindh, $5^{2}$ to the University of Karachi founded in 1951, and a new university - the Shah Abdul Latif University in Khairpur - would be established in the late 1970s. ${ }^{55}$ Accordingly, enrolment numbers at the University of Sindh rose from 644 in

\footnotetext{
53 Alavi, "Pakistan and Islam," 6-7.

54 Habibullah Siddiqui, Education in Sindh: Past and Present (Jamshoro: Institute of Sindhology, University of Sind, 1987), 36o-361.

55 Abad Ahmed Khan, Statistics on Higher Education in Pakistan (Islamabad: University Grants Commission, 1978), 2.
} 
1947 to 3207 in $1974-75$ (with only 320 female students), while the University of Karachi had 7613 students (including 2930 women) the same year. ${ }^{56}$ The development of education in Sindh particularly benefited the sons of small land-owning farmers and schoolteachers, who were often the first in their families to gain access to higher education. They aspired to non-manual urban jobs and often afforded their newly acquired urban lifestyle thanks to agricultural rent. ${ }^{57}$ The role played by the Sindh Madrassatul Islam for the previous generation was now played by the University of Sindh. Indeed, those who resisted centralizing policies of the state by invoking the idea of Sindh often belonged to the social group that benefitted from the expansion of education and experienced their political socialization on the campuses of Sindh.

As Sindhi political elites saw their margin of action against centralizing policies shrink, mobilization then came from writers. In the early 195os, the provincial government's cultural policy established the Sindhi Adabi Board (Sindhi Literary Board), a public institution promoting research and literature in Sindhi. ${ }^{58}$ The SAB, headed by Muhammad Ibrahim Joyo, followed an ambitious program, and supported writers and poets, notably through its quarterly journal Mehran. With the establishment of One Unit in 1955, the SAB lost its patron and suffered a severe setback in funding. The following year, a group of left-leaning writers inspired by the Progressive Writers' Movement established the Sindhi Adabi Sangat (Sindhi Literary Organization) to promote Sindhi literature. ${ }^{59}$ They launched a petition campaign for the defense of the Sindhi language and against its replacement by Urdu. From 196o, the monthly Ruh Rehan became famous for publishing the nationalist poetry of Shaikh Ayaz, which denounced the marginalization of Sindh in the new political set-up and directly condemned Ayub Khan's military dictatorship. Therefore, the implementation of One Unit, followed by the imposition of martial law, pushed a large part of the Sindhi political elite out of the public arena and halted provincial cultural policies, prompting writers to set up private associations.

The nationalist literary production of the time fueled the protests by Sindhi students, who were particularly concerned about their career opportunities now that Sindhi was no more the administrative language in the (former) province. In the 196os, Jamshoro, a town across the river Indus from Hyderabad and

\footnotetext{
$56 \quad$ Khan, 22.

57 Mohammad A. Qadeer, Pakistan: Social and Cultural Transformations in a Muslim Nation (London and New York: Routledge, 2006), 127.

$5^{8}$ Annemarie Schimmel, "The Activities of the Sindhi Adabi Board, Karachi," Die Welt Des Islams 6.3 (1961): 223-243.

59 They revived a network that had been active in the mid-1940s.
} 
the new location of the University of Sindh, became the main center for higher education and the hotbed of political contestation. Left organizations dominated student politics across Pakistan, primarily led by Urdu-speaking men in Karachi and Hyderabad. However, as the Sindhi-Muhajir split grew politically salient in the late 196os, Sindhi students gradually asserted themselves and eventually broke away to establish new organizations. The police violence against protesting students on March 4, 1967, became a landmark event whose resonance as a symbol of the entrance of Sindhi students in large-scale collective mobilization rings to this day. ${ }^{60}$ Another landmark mobilization led by students advocated for voter lists in Sindhi rather than Urdu ahead of the 1970 elections. ${ }^{61}$ During this period, Sindhi student figures and leaders emerged, some of whom, like Jam Saqi, Rasul Bakhsh Palijo, or Akhtar Baloch, would remain active players in Sindhi left and nationalist politics for decades. ${ }^{62}$

The contribution of the "second generation" to Sindhi nationalism is manifold. In terms of political rhetoric, the nationalist idea expressed in the 1930s now combined with left ideology, at a time when the Urdu and Sindhi translation of Stalin's booklet on nations and nationalities was making the rounds of student hostels and campuses under the title Qaum aur Qaumiyyat. ${ }^{63}$ The second generation also massively enriched the Sindhi nationalist imaginary: poetry, prose, research articles, but also films and visual culture, all seem to attempt in one way or another to define the characteristics and origins of Sindh and Sindhis. Cultural institutions such as the Sindhi Adabi Board and later the Institute of Sindhology contributed to fixing a normative conception of Sindhi culture. Identity markers came out of this process. These markers not only defined Sindh and Sindhiness as the land of Sufis and Shah Abdul Latif, of the ajrak and the topi, and of Mohenjo-Daro's 50oo-year-old civilization. They also made a political statement against a centralized conception of Pakistan and its population (e.g., slogans used in demonstrations ["Jiye Sindh"]).

The second generation also brought in a new repertoire of contention. While this generation's predecessors abided by the rules of electoral politics, Sindhi writers and students in the 1950s and 196os did not seek to gain power within state institutions but instead organized against them. Students took to

6o Shaikh Ayaz, et al., 4 March ain Sindhi Jodha (Hyderabad: New Fields Publications, 1978); Aijaz Qureshi, ed., 4 March ain Ajji Sindh (Dadu: Manchhar Publication, 2003).

61 Akhtar Baloch, Prison Narratives (Karachi: Oxford University Press, 2017).

62 It is also worth noting that there is a direct personal connection between these men through the figure of Ibrahim Joyo. Joyo, whose access to education was made possible by G.M. Sayed, taught Hyder Bakhsh Jatoi, Rasul Bakhsh Palijo, and Jam Saqi (Verkaaik, "Reforming Mysticism," 81).

63 Iosif Vissarionovič Stalin, Qaum aur Qaumiat (Faisalabad: Progress Forum, 1962). 
the streets and faced police violence. Writers struggled to issue their periodicals and faced censorship, arrests, and imprisonment. The Sindhi nationalist discourse now combined a well-defined tale of grievance with a historical and cultural narrative. Finally, the second generation was the one that restructured the partisan system of Sindh in the late 196os, particularly after the dissolution of the One Unit in 1969 and the following reinstatement of electoral democracy. Between 1967 and 1973 emerged three distinct political alignments about Sindh's place in the state of Pakistan: the "gradualist" Pakistan People's Party, led by Zulfiqar Ali Bhutto; the "autonomist" group that notably included Rasul Bakhsh Palijo's Awami Tehreek; and the "separatists" of Jiye Sindh Mahaz, led by G.M. Sayed. ${ }^{64}$

\subsection{The "Post-Bangladesh" Generation (1970s-20oos): Radicalization and Violence}

Protest in the late 196os spread to the whole of Pakistan. Eventually, it led to the end of Ayub Khan's military dictatorship, the abolition of the One Unit scheme, the reinstatement of West Pakistan's provinces, and the organization of the first democratic general elections in December 1970. In 1971, after the central authorities refused to accept the election results, East Pakistan seceded and became the independent state of Bangladesh at the cost of a deadly civil war. ${ }^{65}$ The country lost its Eastern half because the central authorities failed to accommodate the demands of one of the state's constituent parts. ${ }^{66}$

Two years after the independence of Bangladesh, G.M. Sayed, who had expressed support for the demands of the Bengali leader Mujibur Rahman before the latter turned separatist, radicalized his political rhetoric and embraced the cause of an independent Sindh - "Sindhudesh."67 Accordingly, he reoriented his political party: the Jiye Sindh Mahaz, founded the previous year as an autonomist party, changed its stance to advocate Sindh's separation from Pakistan. Despite his political isolation, G.M. Sayed enjoyed strong support among Sindhi students: various splits within left student groups had led to the creation of the Jiye Sindh Students Federation in December 1970, which later became the student wing of the separatist Jiye Sindh Mahaz. ${ }^{68}$ Soon, the

\footnotetext{
64 Kennedy, "The Politics of Ethnicity in Sindh," 938-955.

65 Rounaq Jahan, Pakistan: Failure in National Integration (New York: Columbia University Press, 1972).

66 Alyssa Ayres, Speaking Like a State: Language and Nationalism in Pakistan (Cambridge: Cambridge University Press, 2009). Also see Adeel Khan's book Politics of Identity.

67 Both leaders had also met in Karachi in the late 196os.

68 Julien Levesque, "From Student Organizations to Ethnic Parties: Sindhi Nationalism during One Unit," in Pakistan: Alternative Imag(in)Ings of the Nation-State, eds. Jürgen
} 
University of Sindh became a separatist bastion, as the JSSF won elections to the students' union almost every year.

The social profile of these students - the third generation of Sindhi nationalism - was not fundamentally different from that of the second generation. However, what distinguished them was the context of their political socialization, in which being able to use and face violence became an increasingly important quality. Many of the new Sindhi leaders, including the future cadres of the nationalist parties, were trained in this violent environment. Some of JSSF's activists indeed developed new coercive methods. They intimidated Urdu-speaking students - especially at the time of the first "language riots" in 1971 and 1972 - and sympathizers of other political groups - the opposition to the 1973 constitution by nationalists pinned Sindhis against Sindhis. Weapons became available on campuses and used in isolated clashes or targeted actions. In the first instance of lethal violence, two students were killed at the University of Sindh in October $1973 \cdot{ }^{69}$ In July 1975, some JsSF students abducted an Urdu-speaking provincial minister. ${ }^{70}$ In the 1980s, the use of weapons extended to collective action as political rivalries gave way to ethnic conflict, with each group - Sindhi, Mohajir, Punjabi - represented by its organizations. Emerging as a student leader increasingly entailed organizing protection and retaliating violently, but student organizations also engaged in protection racket and developed links with bandits. ${ }^{71}$

In the late 1980s, the new turbulent leadership clashed with the old guard the founders of the Jiye Sindh Mahaz - over violence, initiating a systematic and recurring process of fragmentation for the nationalist party. ${ }^{72}$ Other differences instilled division within the ranks: the question of the boycott of the electoral process, the place granted to non-ethnic Sindhis within parties and alliances, the links with criminal groups, and personal rivalries. Despite attempts at unification, factions within the Jiye Sindh Movement went from two in 1990 to about a dozen in the 2010s. Fragmentation led to the diversification

Schaflechner, Christina Österheld, and Ayesha Asif (Karachi: Oxford University Press, 2020), 246-285.

69 The murder of two students (i.e., Ali Mardan Shah and Jan Muhammad Khuhro) that supported Z.A. Bhutto's party by nationalist activists illustrates Sindhis' political divisions regarding the sitting government and the new constitution. On this event, see Tahir, Political Dynamics of Sindh, 707 .

70 G.M. Sayed and the JSM condemned the move, and the minister, Badi ul-Hasan Zaidi, was released within a day (Soomro, The Path Not Taken, 200).

71 Christina Lamb, Waiting for Allah: Pakistan's Struggle for Democracy (New Delhi: Viking, 1991), 121-135.

72 The student nationalist leadership that emerged in the 1980s notably included Bashir Khan Qureshi and Qadir Magsi. 
of the repertoire of action of nationalist parties that claim G.M. Sayed's heritage: some have abandoned the separatist goal and accept electoral politics; others follow non-violent non-electoral politics, in effect becoming pressure groups; and a small fraction has opted in the 2ooos for armed struggle.

For the third generation, violence also came from the state. In November 1973, with the "disappearance" of a Hindu teacher from the University of Sindh, who was close to the Jiye Sindh Mahaz, Z.A. Bhutto initiated dealing with subversive political groups through extrajudicial killing, often named "enforced disappearances" in Pakistan. ${ }^{73}$ The various military operations initiated by the state from the 1980s in Sindh have often made an insufficient distinction between political opponents and criminals, thus creating widespread resentment within the population against the military.

Sindhi student leaders also distinguished themselves with their capacity to face violence and play a defensive role if needed, thus including violence in the repertoire of Sindhi nationalism. On September 30, 1988, a group of armed men on motorbikes drove through Urdu-speaking neighborhoods of Hyderabad and shot indiscriminately at people, leaving more than 250 dead, and initiating a series of killings against Sindhis in retaliation. Many think Qadir Magsi, the leader of the "Taraqqi Pasand" wing of the JssF, had planned this move, along with the dacoit Janu Arain. ${ }^{74}$ Ethnic violence contributed to segregating communities, as there was a significant migration of Urdu-speaking people who had settled in the countryside and the small towns of Sindh to the cities of Hyderabad and Karachi. Urban expansion established new ethnically homogeneous neighborhoods within these two cities, such as Latifabad and Qasimabad in Hyderabad.

The violent context within which nationalist activists were socialized left them more exposed than their elders to economic hardships. The overall atmosphere on university and college campuses deteriorated, pulling down the level and quality of education. The administration often closed campuses for months because of disturbances, increasing the duration to obtain degrees and lowering their value. Students who graduated from colleges and universities in Sindh were poorly trained to face the job market, with often poor spoken

73 There are widespread allegations that the Pakistani security forces use "enforced disappearances" of Sindhi and Baloch leaders to weaken groups that advocate independence from Pakistan. Political activists from other groups, notably the Muttahida Qaumi Movement, are also targeted. See the regular press releases of the Human Rights Commission of Pakistan on this matter (for instance, see "Time to Rid Pakistan of Disappearances Is Now" from 2017).

74 This fact is no secret, as Qadir Magsi publicly plays with his reputation and prides himself in being called the "Che Guevara of Sindh." 
and written English and sometimes uncertain written Urdu. While many in the second generation had benefitted from Bhutto's rise to power, young university graduates in Sindh in the 1980 s risked being part of the urban proletariat in case of a failed social mobility. This situation was particularly the case for political workers who had been more involved in their activism than their studies. Moreover, because they boycotted most elections, nationalist parties had little to offer in terms of political career. Nationalist parties thus seemed to accept a role as pressure groups, able to raise issues then taken up by mainstream parties.

Combined with state repression and violent clashes with other groups, this made it difficult for nationalist workers to maintain their level of commitment. Many settled for one of the following three options to pursue their political engagement outside nationalist parties - when they did not simply go back to their village. Some chose to move abroad, mainly to the UK and the US, often both for political and economic reasons, and to take part in community organizations that lobby for Sindh's auto-determination - the Sindhi Association of North America (founded in 1986) or the World Sindhi Congress (1988). Others joined the vibrant Sindhi vernacular media that emerged in the late 1980 os and early 1990s: the editors and journalists working with the two leading Sindhi newspapers, Awami Awaz and Kawish, nearly all have been "comrades" (active in left and nationalist groups) in the past. Others still found employment within the budding network of NGOs, both international and local. The latter, such as the Pakistan Fisherfolk Forum, often work as advocacy and lobbying groups rather than development organizations. Since the 199os, this network of political activists, NGO workers, and journalists, thrives in the Qasimabad neighborhood of Hyderabad - the center of the educated Sindhi middle class.

In the 2010s, many sympathizers remained in favor of the separatist cause and mobilized on specific occasions. The large "Freedom March" held in Karachi in March 2012 is a case in point. However, the chief organizer, the Jiye Sindh Qaumi Mahaz (Long live Sindh National Front), has lost ground since then. Its leader, Bashir Khan Qureshi, died in mysterious circumstances shortly after the march, precipitating the party into dynastic politics as his inexperienced 19-year-old son was promoted to the leadership position. Police and military operations initiated after Nawaz Sharif came to power in 2013 further rolled back the organizational capacity of nationalist parties and reduced their presence from public spaces. However, the crackdown on nationalist organizations did not destroy the networks and connections between like-minded people sympathetic to the nationalist cause.

Thus, as this section shows, Sindhi nationalism is not a reflex reaction that occasionally expresses itself in an anti-state outburst. Instead, it is a discourse 
centered on an idea of Sindh shaped by various political and social actors over a century. These actors built on their predecessors in defining what Sindhi identity means and how it is represented. They also added to the repertoire of action of nationalist organizations. It would be a mistake to reify "Sindhi nationalism": the political demands based on the "idea of Sindh" changed according to the historical context. Yet the contributions of the three generations acted upon an idea of Sindh rooted in an ethnic understanding of human societies. From the separation movement to supporting the Pakistan project, to attempts at building a loyal opposition and later separatist positions, the very idea that Sindhis constituted a cultural and historical entity that deserved a political existence remained the principal driver. At times, the idea of Sindh informed actions that sought to challenge the nationalist narrative promoted by the state. However, it was not always the case. The idea of Sindh seemed compatible with the Pakistan project to many Sindhis in the 1940s, and Z.A. Bhutto gave a central space to Sindh in his cultural policy predicated upon the idea of Pakistan being composed of four ethnic groups.

\section{Beyond Mobilization: The Broader Diffusion of the Idea of Sindh}

While the promoters of the Sindhi nationalist discourse after Pakistan's independence mainly belonged to an aspirational middle-class, the diffusion of the idea of Sindh impacted society more broadly. This impact appears in the widespread recognition of Sindhi identity markers as expressions of Sindhiness or even signifiers of Sindh. At the parades and shows that take place during the yearly cultural festival (the "Sindhi Saqafati Diharo" or "Sindhi Topi Day") initiated in 2009, no one seems to question the constructed nature of the symbols that people brandish. To all, they are nothing but the symbols of Sindh.

To understand how the nationalist way of thinking about Sindh spread in society and changed the way people conceive of themselves and act in public space, one needs to apprehend nationalism beyond nationalist parties and beyond nationalist mobilization. Nationalism is not simply a political stance (i.e., believing in and advocating the independence of Sindh). It is also a social process - the transformation by which a particular criterion of belonging, such as an ethnic criterion, becomes the principal category through which individuals think of their society and its divisions. This redefinition implies that the link between the "cognitive dimension" of nationalism and "ethnic boundaries" is crucial to understanding nationalism. ${ }^{75}$ In other words, we need to look

75 On the cognitive dimension of nationalism, see Rogers Brubaker, Ethnicity Without Groups (Cambridge: Harvard University Press, 2004), 17-18. On group boundaries, see 
at the contest between people and groups of people in spreading or imposing their ways of thinking about the social world - and how, in this process, this same way of thinking about the social world is constituted and changes social relations. To better apprehend the broader contribution of Sindhi nationalism to Pakistan's politics, this section examines how the idea of Sindh translated into the institutional realm - cultural policy on the one hand and electoral politics on the other.

\subsection{Cultural Policy: Institutions for a Pluralistic Idea of Pakistan}

The imprint of Sindhi nationalism is perhaps most evident in the realm of cultural policy. The historical and cultural narrative of Sindh as a distinct socio-political entity, although it infused the Pakistan project, soon clashed with the centralized and abstract conception of the Pakistani nation that was gradually defined in the 1950s and then promoted by the state after Ayub Khan took power in 1958. The nation-building project of the Pakistani state aimed at producing a citizen not defined by primordial attachments - linguistic, tribal, or caste-based - but by language (Urdu) and religion (Islam). This ideal pervaded the new teleological narrative that became official textbook history: authors like Ishtiaq Hussain Qureshi and Sheikh Muhammad Ikram propounded, under the auspices of the Pakistan Historical Society and the Institute of Islamic Culture, a view of South Asia that sought to highlight the distinctiveness of Muslims, justifying the "natural" aspiration for a separate state that led to the birth of Pakistan. ${ }^{76}$

Against this official history, Sindhi researchers - historians, folklorists, literary specialists - elaborated on the narrative of Sindh sketched during the separation movement. While the idea of Pakistani-ness rested on abstract

Fredrik Barth, Ethnic Groups and Boundaries: The Social Organization of Culture Difference (Middleton, Connecticut: Waveland Press, 1998).

76 Ali Usman Qasmi, "A Master Narrative for the History of Pakistan: Tracing the Origins of an Ideological Agenda," Modern Asian Studies 53.4 (2019): 1066-1105. I.H. Qureshi's work pursued initiatives started before independence within the Pakistan National Movement, of which he had been a member. The Pakistan National Movement, founded by the very person who coined the name Pakistan, Chaudhry Rahmat Ali, imagined in a series of pamphlets what Pakistan was in "antiquity" and its evolution over more than a millennium (See Ayres, Speaking Like a State, 106-110). For a criticism of official history writing in Pakistan, see Khursheed Kamal Aziz, The Murder of History: A Critique of History Textbooks Used in Pakistan (Lahore: Vanguard, 1993); Ayesha Jalal, "Conjuring Pakistan: History as Official Imagining," International Journal of Middle East Studies 27 (1995): 73-89. For the writings of I.H. Qureshi and S.M. Ikram, see for example Ishtiaq Husain Qureshi, The Pakistani Way of Life (New York: Praeger, 1956); Ishtiaq Husain Qureshi, The Muslim Community of the Indo-Pakistan Subcontinent, 610-1947: A Brief Historical Analysis (Gravenhage: Mouton, 1962); Sheikh Muhammad Ikram, History of Muslim Civilization in India and Pakistan: A Political and Cultural History (Lahore: Institute of Islamic Culture, 1962). 
denominators of identity, Sindhiness was, in their view, concretely rooted in a shared cultural experience. This experience stretched since the days of Mohenjo-Daro and in concrete ties that made Sindhis one people - language and shrine-based religiosity standing out prominently in the list of collective binders. Not only did G.M. Sayed write books that expounded this political vision, but Sindhi researchers reinforced this myth of origins by invariably starting their inquiries from the Indus civilization, whatever the subject at hand. ${ }^{77}$ A good example of this approach is the influential Sindhi boli (Sindhi language) written by Siraj ul-Haq Memon in 1964. It describes Sindhi as the mother of Sanskrit and other north Indian languages, and the Indus civilization as a golden age that engendered both the Vedic and Mesopotamian civilizations:

[I]n the pre-historic era, there was a period in which a nation existed in the region extending from Harappa to Mohen-jo-Daro, i.e., from present Sindh and some areas of Punjab in its north, that was civilized in all aspects and possessed a fully developed civilized culture and had a spoken as well as written language. The people were disciplined, cultured, and more prosperous than other nations in the world ... approximately in $5000 \mathrm{BC}$, this nation had a language that, with some exceptions, still prevails in the present-day Sindh region. It was a purely indigenous language which was free of any foreign influence. ${ }^{78}$

77 Because of the lack of sources or information, such reflections were often either speculative or rhetorical. For instance, see Ghulam Ali Allana, ed., Folk Music of Sind (Jamshoro: Institute of Sindhology, 1982), 1. See also: Siddiqui, Education in Sindh, 2-5. For G.M. Sayed's books, see for instance G.M. Sayed, Shah Latif and His Message (Sehwan Sharif: Saeen Publishers, 1996); G.M. Sayed, Religion and Reality (Lahore: Fiction House, 1986). Also see G.M. Sayed's book Sindhudesh: A Study in Its Separate Identity Through the Ages.

78 Siraj Memon, Sindhi Language (Hyderabad: Sindhi Language Authority, 20o9), 67. This book responded to those who argued that the Sindhi language was an Indo-European language born out of Prakrits. These included Western scholars such as Ernst Trumpp and Sindhi Hindus like Bherumal Mehrchand Advani (Bherumal Mahirchand Advani, Sindhi boli ji tarikh [Hyderabad: Sindhi Adabi Board, 1956]). It also responded to those who saw Sindhi as a Semitic language. This view was, at the time, the relatively isolated perspective of Nabi Bakhsh Baloch, who later changed his mind and even drew an index of Sindhi words that he identified as indigenous because they had no parallels in other languages (See Nabi Bakhsh Khan Baloch, "Sindhi Tahzib ji Sindhu Likhat ji Bhan," Sindhi Boli [1994]). Siraj Memon's book gained tremendous popularity. Generations of students read it since it was on the syllabus of the University of Sindh (on the impact of this book on Sindhi "collective consciousness," see the introduction to the English edition of the book by the director of the Sindhi Language Authority and, incidentally, Siraj's sister, Fehmida Hussain). 
Manan Ahmed summarizes the contemporary resonance of the opposition between Pakistan's official discourse and the Sindhi nationalist narrative. He states: "The memory of a 5,00o year old Sindhi qaum is rigorously debated in everyday public spaces with just as much fervor as the originary myth of the nation-state of Pakistan is preached to the citizens of Pakistan."79

Interestingly, the scholars behind the Sindhi historical narrative worked with state support and provincial cultural institutions often sponsored their research. Like educational measures, such cultural institutions had their roots in government pre-independence initiatives at the provincial level. In 1940, G.M. Sayed, education minister in Mir Bandeh Ali Khan Talpur's cabinet, founded the Central Council for the Support of Sindhi Literature (sindhi adab lae markazi salahkar board). This council, in December 1951, became the Sindhi Adabi Board. ${ }^{80}$ The SAB, headed by Muhammad Ibrahim Joyo, had serious ambitions concerning research and publication. Its program included writing a ten-volume history of Sindh (never completed), a linguistic project (grammar and dictionary), and a plan for folklore documentation that was to comprise 47 volumes. ${ }^{81}$ The person that was leading the latter project, Nabi Bakhsh Baloch, later became the director of another Sindhi cultural organization: the Institute of Sindhology, first established in 1963 as the Sindh Academy, before being renamed in 1970 in a way that, inspired by Indology or Egyptology, expressed its founders' hope of constituting "Sindh Studies" as a recognized discipline. Nabi Bakhsh Baloch later coordinated the establishment of yet another cultural institution, the Sindhi Language Authority, in 1990.

Apart from the continuity in people, there was a palpable intellectual filiation, as these three institutions constructed a nationalist body of knowledge. On the one hand, Sindh-centric history-writing produced the material that a nationalist narrative could rephrase, which highlighted heroes of resistance against invaders and enemies. ${ }^{82}$ On the other hand, the folklore documentation project, drawing inspiration from colonial ethnography, collected,

79 Manan Ahmed, "The Many Histories of Muhammad B. Qasim: Narrating the Muslim Conquest of Sindh," Ph.D. diss., University of Chicago, 2008 (https://archive.org/stream/ TheManyHistoriesOfMuhammadB.Qasim/The+many+histories+of+Muhammad+b.+Qa sim_djvu.txt [accessed August 8, 2021]).

8o The status of the Sindhi Adabi Board changed in 1955 when it became an independent institution registered under the Societies Registration Act XXI. Some of the working documents and minutes of the SAB are at the International Institute of Social History, Amsterdam (G.M. Sayed Archive, file no. 16).

81 "Only" 42 volumes on Sindhi folklore were eventually published between 1959 and 1991 under the leadership of Nabi Bakhsh Baloch.

82 See G.M. Sayed, "Sindh ja Surma," for specific historical figures, in Sain Ji Em Sayed jon tehriron, vol. 6 (Sann: G.M. Syed Academy, 2011), 57-92. 
indexed, and hence fixed what scholars saw as the fast-disappearing Sindhi culture. The project categorized cultural diversity to create unity: a variety of ways of living and speaking, now labeled Sindhi, was presented in books and museums, such as the Sindh Museum in Hyderabad or the museum of the Institute of Sindhology in Jamshoro. ${ }^{83}$ Thus, cultural institutions engaged in a process of folklorization, which I define as inventorying and re-enacting cultural practices and references to turn them into essentializing, conscious identity markers eventually. ${ }^{84}$ The result was a conception of Sindhi culture reduced to specific elements - tales, songs, dress, craftsmanship - now ready to acquire new political meaning as expressions of Sindhiness.

The cultural policy of "Sindhology" pursued in Sindh had an impact at the all-Pakistan level. When Zulfiqar Ali Bhutto came to power in the early 197os, he bent the official unitary doctrine towards a more pluralistic vision of Pakistan and its population. Instead of defining the Pakistani citizen in terms of Islam and Urdu, official nationalism now acknowledged "regional" cultures as part of the "national" whole. To showcase this new state nationalism, Z.A. Bhutto had an international conference organized on Sindh in March 1975 (all four provinces were to have similar events). Perhaps more importantly, he established the National Institute of Folk and Traditional Heritage, more commonly known as the Lok Virsa, in 1974. The Lok Virsa was a direct reproduction at the national Pakistan level of the Sindhi institutions and notably engaged in documenting Sufism and shrine culture as expressions of "popular" Pakistani culture. ${ }^{85}$ Z.A. Bhutto's government officially promoted this inclusive nationalism, and the historical narrative was perhaps best phrased by the prominent PPP leader Aitzaz Ahsan, a reputed lawyer and former minister. In his book The Indus Saga and the Making of Pakistan, Aitzaz Ahsan dissociated the foundation of Pakistan from the two-nation theory and portrayed it as the logical outcome of a profound civilizational difference between Hind the Gangetic plains - and Sindh - the Indus valley. ${ }^{86}$ Whether he knew it or not, Aitzaz Ahsan was reiterating a distinction that, drawn from medieval

83 See, for instance, Ghulam Ali Allana, Sindhi Society and Culture (Karachi: Culture Department of the Government of Sindh, 2010).

84 On folklorization, see Mark Rogers, "Spectacular Bodies: Folklorization and the Politics of Identity in Ecuadorian Beauty Pageants," Journal of Latin American Anthropology 3.2 (1998): 54-85.

85 David Gilmartin, "Sufism, Exemplary Lives, and Social Science in Pakistan," in Rethinking Islamic Studies:From Orientalism to Cosmopolitanism, eds. Carl Ernst and Richard C. Martin (Columbia: University of South Carolina Press, 2010), 159-178.

86 Aitzaz Ahsan, The Indus Saga and the Making of Pakistan (Karachi: Oxford University Press, 1996), 9-20. 
Arabic and Persian manuscripts, was central to Sindhi nationalist claims of cultural and political distinctiveness throughout history.

The official cultural policy of Pakistan, without discarding the state's founding principles, fluctuated over time. After Z.A. Bhutto was ousted and hanged, Zia ul-Haq again emphasized Islam as the common denominator and patronized groups that promoted such a vision - religious parties and their scholarly organizations. Celebrating the cultural diversity of Pakistan - in Sindh, celebrating Sindhi culture - again became subversive. In this way, shifts in state policy displaced the limit between acceptable cultural assertion and inflammatory political statement, acting as a major structuring factor in what cultural institutions could or not publish. Yet folklorization is, by essence, equivocal. If folklorization can be an act of resistance against a homogenizing state policy, it may also serve to neutralize the subversiveness of identity assertion by representating the said identity as rigid "museified" cultural heritage. In Sindh, folklorized culture was used in different ways by Sindhi separatists and by Z.A. Bhutto and the PPP. The former extolled the folklorized vision of Sindh as the ultimate justification for their demand of independence. Conversely, Z.A. Bhutto used the same conception to assimilate Sindhi identity within a broader framework of Pakistani nationhood - depoliticized but preserved. This use would not have been possible without the intellectual and political engagement of the previous generations of Sindhis in constructing an idea of Sindh as a socio-political unit.

\subsection{Sindhi Nationalists and Sindh's Political Arena}

In mainstream electoral politics, Sindhi nationalism as a discourse and Sindhi nationalist parties have had a much more significant impact than their relatively low numerical strength may suggest. Journalists and commentators often decry the use, when the PPP seems to be losing ground in public opinion, of the so-called "Sindh card" - that is, the conscious reference by politicians to injustices committed against Sindhis by the Pakistani state. ${ }^{87}$ However, they rarely explain the appeal of such references for Sindhi voters, seeing only a misuse of public sentiment by shrewd office-seekers. Analysis should unpack this fact: how does Sindhi nationalism as a discourse connect separatist and autonomist parties with mainstream political agenda-setting in Sindh and Pakistan?

87 Bina Shah, “The Sindh Card," Dawn, February 6, 2010 (http://www.dawn.com/2010/o2/o6/ the-sindh-card/ [accessed August 8, 2021]); Hasan Mujtaba, "Pakistan Mein Sindh Kard ki Haqiqat," BBC Urdu, January 3, 2010 (http://www.bbc.com/urdu/pakistan/2010/o1/100103 _sindh_card_zee.shtml [accessed August 8, 2021]). 
Such a question is approachable from the angle of political socialization. Many active members of the PPP, the Awami Tehreek, and the Jiye Sindh movement share similar social trajectories. Until the 199os, they made their political socialization in the same context - the universities and colleges of Sindh - where they read G.M. Sayed, communist literature, and the poetry and stories written by Sindhi litterateurs since the 1950s. As a result of this intellectual training, they share a political outlook rooted in left-wing principles and nationalist leanings. However, they differ on the ultimate place for Sindh as independent or part of Pakistan and the strategies for reaching it (e.g., electoral, or non-violent opposition). They also often took part in the same struggles: although G.M. Sayed refused to support the Movement for the Restoration of Democracy in the 1980s, many of his supporters chose to individually participate in MRD protests, as they considered it as a movement of resistance against the military regime, whose primary social moorings were in Punjab. As a result of a common political socialization, a large section of the Sindhi political class forms a network of interpersonal connections, sometimes dating to student days.

The common intellectual background and personal interconnections made it possible for many nationalists from Jiye Sindh and Awami Tehreek to defect to the PPP. One of the current stalwarts of the PPP in Sindh, Gul Muhammad Jakhrani, is a case in point. A man of the "third generation," he asserted himself as a Sindhi separatist leader in the 1980s, and, along with Bashir Khan Qureshi, established a separate faction when the old guard of Jiye Sindh Mahaz refused to accept them on the allegation that they were involved in violent and criminal activities. He remained an active member of various separatist groups until the mid-2ooos and eventually joined the PPP to run (successfully) in a by-poll election in late 2008. During his mandate as Member of the National Assembly (2008-2013), Gul Muhammad Jakhrani's public interventions adopted an emotional, nationalist tone, arguing for the defense of Sindh's rights, invoking the ancientness of Sindhi culture, and denouncing the injustices that Sindhis must now endure. ${ }^{88}$

Such transfers of activists from Sindhi nationalist groups to mainstream parties - due notably to state repression and career opportunities the fringe parties cannot offer - have been happening since the 1970s, thus contributing

88 See, for instance, his 2010 speeches on Sindh's water deprivation (https://youtu.be/ KAv5qE4FsAU [accessed August 8, 2021]) or his reading of Pakistan's history and denunciation of military domination (https://youtu.be/-i5j3Wl $4 \mathrm{Pr}_{4}$ [accessed August 8, 2021]). In the latter, Gul Muhammad Jakhrani recounts the October 1984 shooting of nationalist students by the military at Thori Phatak, leaving five people dead. 
to the diffusion of the nationalist idea of Sindh. The dense network between nationalist parties and the PPP - and, since the 1990s, NGOS - indicates that they participate in a single political arena, in which separatist parties have endorsed their own institutionalized space as pressure groups. Causes raised by nationalist and autonomist parties tend to be taken up by the PPP on the electoral stage and in elected bodies. There are specific issues on which the Sindhi political class stands united. One of these is the water-sharing problem, Sindh being in a dependent, riparian position in relation to upstream Punjab, Pakhtunkhwa, and Kashmir. In the mid-20oos, the autonomist party Awami Tehreek managed to garner significant support against the construction of the Kalabagh Dam on the Indus River after Pakistan's President General Pervez Musharraf publicly revived the project in December 2004. Numerous political actors and intellectuals came forward, alleging that the proposed barrage would impact an already water-stressed Sindh. They signed a "Charter of Demands" that retold Sindh's narrative of grievance from Pakistan's inception and argued in favor of significant autonomy. About goo people signed the charter drafted by the Awami Tehreek. Many political parties (including various autonomist parties, the PPP, religious parties such as the Jamiat Ulama-i Islam, the Punjab-based Pakistan Muslim League-Nawaz) and civil-society or cultural organizations (such as the Sindhi Adabi Sangat and the World Sindhi Congress) supported it. According to the text itself, the charter was approved by "more than sixty thousand Haree [peasant] \& mazdoor [laborer] activists." Except for one signatory, however, Sindhi separatists were conspicuously absent from the petition because of its clear autonomist stance. While the Awami Tehreek was instrumental in building a platform to voice a united opposition, separatist groups who had not signed the charter mobilized public opinion by bringing people onto the streets, staging sit-ins, and conducting hunger strikes against the Kalabagh Dam project. Opposition by Sindhi politicians against the project has been constant since Zia ul-Haq pushed for it in the 1980s. The Sindh assembly has repeatedly voted unanimously in support of resolutions against the project, as have the provincial assemblies of Khyber-Pakhtunkhwa and Baluchistan. When the PPP came to power at the center in 2008, it chose to shelve the project, but the debate is regularly rekindled by politicians from Punjab, bureaucrats, or the military. ${ }^{89}$ This widespread consensus that translates into political decisions within the institutional realm stems from the sense of shared interest that rests in the belief that Sindh exists as a political

89 Tarique Niazi, "Contesting Instrumental Knowledge with Communicative Action: Why Kalabagh Dam (Pakistan) Remains Unbuilt," Organization \& Environment 32.4 (2019): $441-465$. 
community and is entitled to rights over its territory and population - in this case, the rights of a lower riparian.

This example shows that public controversies in Sindh are often constructed in connection with nationalist conceptions of the political community. This fact is possible because many Sindhi politicians in the PPP and other mainstream parties have experienced shared political socialization along with separatists on Sindh's university campuses. Other examples could include questions of decentralization (the 1973 Constitution, the 18th amendment, Local Government Bill, NFC award), resources (oil, gas, coal), or the management of immigration (significantly, in recent years, internally displaced persons from the Khyber-Pakhtunkhwa province and the Federally Administered Tribal Areas).

\section{4 \\ Conclusion: Co-constructed Nationalisms?}

A key argument in this article is that focusing on whether Sindhi nationalism is or is not a failure has overshadowed much of what it has achieved. The incapacity of separatist and autonomist parties to shake the Pakistani state diverts attention away from better understanding the "idea of Sindh." It deflects attention away from how nationalist principles inform understandings of Sindh and Sindhi identity and their broad diffusion in the Sindhi public sphere. Instead of focusing on failure or success, this article shows that constructing a nationalist concept of Sindh has been a continuous process spanning the twentieth and twenty-first centuries. This process translates into institution-building in the cultural sphere and contributes to the political outlook of a large section of Sindhi politicians on the left of the spectrum.

As this article highlights, the Sindhi nationalist discourse should be understood as socially constructed. Three generations of Muslim men, sharing similar trajectories but with distinct social characteristics and repertoires of contention, reinforced and disseminated it. After Pakistan's independence, members of an aspirational middle-class crafted and promoted the idea of Sindh. Moreover, I showed that the production of the idea of Sindh implied a tremendous creative engagement on its proponents. In the process of "folklorization," Sindhis identified specific cultural elements - notably Sufism and folk culture - that have been turned into identity markers by scholars before becoming ubiquitous in the public space, particularly in visual productions. With an aim to identity assertion, Sindhis established cultural institutions that were later replicated at the national Pakistan level. This paper also highlights 
the central role of G.M. Sayed as the founding father of Sindhi nationalism, both in the realm of ideas and institutions. Finally, this article opens the way for further study into the impact of Sindhi nationalism on society and politics in and beyond Sindh. Not enough is known about the way critics or opponents have engaged with Pakistan's nation-building project. This article thus points towards the fact that scholars should examine Sindhi nationalism in its co-constructive relation with the Pakistani state's conception of nationhood. Greater exploration of Sindhi nationalism and its relation to the Pakistani nation-building project would yield more detailed knowledge on the socio-political transformation that it induced. This exploration could start with missing or overlooked aspects of the narrative depicted here in this article. Examples include the 1940s Hur movement, the differing conceptions of "Sindhiyyat" by Sindhi Hindus and minority groups like the Sheedi, and the links between the various nationalist movements in Pakistan's "smaller provinces."

In recent years, the Pakistani state apparently seeks to subdue nationalist demands by replicating a Chinese model (i.e., economic growth through infrastructural investment with limited political rights). But nothing eliminates the possibility of new instances of widespread nationalist mobilization in Sindh. Since 2013, the Pakistani state's severe repression of dissident organizations has targeted not only terror groups, but also ethno-nationalist political outfits (like the MQM in Karachi as well as Sindhi and Baluch nationalists). This crackdown has strongly weakened Sindhi nationalist parties after several years of heightened activity under PPP rule at the central level. Yet, the revival of Pashtun nationalism under the umbrella of the Pashtun Tahaffuz Movement suggests that there is scope for ethnic politics in Pakistan. For Sindh, the central authorities' capacity to accommodate Sindhis within the power structure and grant them economic opportunities on par with Punjab and Karachi is likely to remain a significant determinant. 